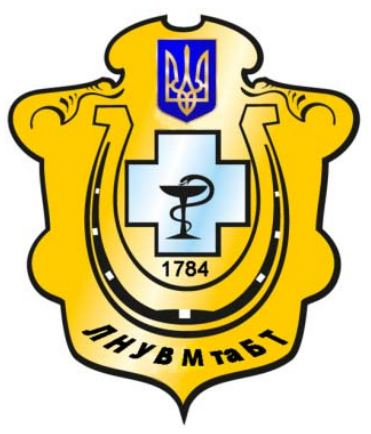

Науковий вісник Львівського національного університету ветеринарної медицини та біотехнологій імені С.3. Гжицького

Scientific Messenger of Lviv National University of Veterinary Medicine and Biotechnologies named after S.Z. Gzhytskyj

doi:10.15421/nvlvet7031

ISSN 2413-5550 print

ISSN 2518-1327 online

$\underline{\text { http://nvlvet.com.ua/ }}$

УДК 619:612.13

\title{
Відмінності складу крові периферичних і центральних вен у свиней
}

\author{
Д.В. Кібкало, С.Б. Боровков, М.І. Коренев, В.М. Боровкова, Х.А. Попова \\ diagnost_96@ukr.net
}

Харківська державна зооветеринарна академія,

смт Мала Данилівка, Дергачівський р-н, Харківська обл., 62341, Украӥна

\begin{abstract}
Вивчено питання правомірності співставлення результатів дослідження крові з центральних вен з нормативами розробленими на основі капілярної крові та крові периферичних судин. Дослідженнями встановлено, що кількість гемоглобіну, еритроцитів та лейкоиитів в судинах різного діаметру достовірно не відрізняється. Для підрахунку різних форм лейкочитів кров потрібно відбирати з периферичних судин. При встановлені лейкоцитарного профілю з різних судин були встановлені наступні відмінності: в крові з вушної вени вірогідно містилася більша кількість еозинофільних гранулоцитів, кров краніальної порожнистої вени та очного синусу містила вірогідно вищу кількість лімфоцитів, в крові $з$ порожнистої вени взагалі не виявлено моноцитів та базофільних гранулоцитів.
\end{abstract}

Ключові слова: поросята, методи взяття крові, морфологія крові, лейкоцити, еритрочити, гемоглобін, імунітет.

\section{Отличия состава крови переферических и центральных вен у свиней}

\author{
Д.В. Кибкало, С.Б. Боровков, Н.И. Коренев, В.Н. Боровкова, Х.А. Попова \\ diagnost_96@ukr.net
}

Харьковская государственная зооветеринарная академия, пгт Малая Даниловка, Дергачёвский р-н, Харьковская обл., 62341, Украина

\begin{abstract}
Изучен вопрос правомерности сопоставления результатов исследования крови из центральных вен с нормативами, разработанными на основе капиллярной крови и крови периферических сосудов. Исследованиями установлено, что количество гемоглобина, эритроцитов и лейкоцитов в сосудах различного диаметра достоверно не отличается. Для подсчета различных форм лейкоцитов кровь нужно отбирать из периферических сосудов. При установке лейкоцитарного профиля из разных сосудов были установлены следующие различия: в крови из ушной вены достоверно содержалось большее количество эозинофилов, кровь краниальной полой вены и глазного синуса содержала достоверно большее количество лимфоцитов, в крови с полой вены не обнаружили моноцитов и базофильных гранулоцитов.

Ключевые слова: поросята, методы взятия крови, морфология крови, лейкоциты, эритроцичты, гемоглобин, иммунитет.
\end{abstract}

\section{Differences of blood peripheral and central venous in pigs}

\author{
D.V. Kibkalo, S.B. Borovkov, N.I. Korenev, V.N. Borovkova, Kh.A. Popova \\ diagnost_96@ukr.net
}

Kharkiv state veterinary academy,

Mala Danylivka, Kharkiv region, Dergachi district, 62341, Ukraine

\section{Citation:}

Kibkalo, D.V., Borovkov, S.B., Korenev, N.I., Borovkova, V.N., Popova, Kh.A. (2016). Differences of blood peripheral and central venous in pigs. Scientific Messenger LNUVMBT named after S.Z. Gzhytskyj, 18, 3(70), 132-135. 
Among laboratory researches in animals the most widespread is the common blood test that can determine hidden changes in organs and tissues, monitor the effectiveness of therapeutic and preventive measures to predict outcome of disease. The question of the legality comparing the results of blood analysis from central veins with rates that are developed from capillary and peripheral vessels blood is studied in the article. Researches were conducted in seven pigs of ukrainian white breed in age 2-4 months. Blood was collected in the morning before feeding by puncture of ear vein, orbital sinus and cranial vena cava. From each animal were picked out 3 blood samples. For taking blood were applied the vacuum blood collection systems. In blood were determined the number of erythrocytes, leukocytes and hemoglobin by conventional methods (Kibkalo et al., 2016). From the results of leukocyte profile the major differences were found in the number of eosinophils whose content was significantly higher ( $r \leq 0.001)$ in the blood of ear veins. Should be noted that this index was much higher than the norm, which is possible associated with the pathological process. But their level in blood of the cranial vena cava and eye sinus was normal. Therefore, this question needs further study. Also found significantly lower $(r \leq 0.01)$ level of lymphocytes in the blood from the ear vein. In the vena cava were not found monocytes and basophils unlike eye sinus and ear veins, in the last their detected more. Based on the foregoing, it can be noted that in the blood of peripheral veins are registered larger number of granulocytes, which in future will be tissue macrophages. Neutrophils, monocytes, basophils and eosinophils have the ability to attach to the capillaries and small vessels walls. So they are providing the cellular immunity. In blood of central vessels are more lymphocytes that provides humoral immunity in the bloodstream. Perspectives of the next studies will be comparing the hematological results that are realized on automatic hematology analyzer from ear vein, eye sinus and cranial vena cava from the same piglets.

Keywords: pigs, blood collection methods, the morphology of blood, leukocytes, erythrocytes, hemoglobin, immunity.

\section{Ветуп}

Серед лабораторних досліджень у тварин найпоширенішим $є$ загальний аналіз крові, який дозволяє виявити приховані зміни в органах і тканинах, контролювати ефективність лікувальних і профілактичних заходів, прогнозувати результат захворювання.

Актуальність теми. Згідно 3 методиками проведення лабораторних досліджень, кров у тварин, в тому числі у свиней, відбирають 3 периферичних судин (вушної або підхвостової вени), також для морфологічних досліджень крові рекомендується досліджувати капілярну кров. В останні роки значного поширення набуває практика взяття крові у свиней з очного синусу або ж краніальної порожнистої вени (Kibkalo et al., 2016; Borovkova, 2015). Тому, постає питання, про можливі відмінності клітинного складу крові в периферичних і магістральних судинах, та наявність достовірних відмінностей в складі крові відібраної з різних судин. Актуальним це питання є i тому, що на сьогоднішній день дослідження проводять на автоматичних гематологічних аналізаторах, які призначені для дослідження венозної крові з великих судин, що ставить під сумнів можливість використання нормативних показників і правильність трактування отриманих результатів встановлених для крові дрібних периферичних судин.

Так за даними дослідників (Nikitin, 1956; Levchenko, 2010) кількість формених елементів в великих магістральних венах менше в середньому на $20-25 \%$ ніж к крові з вушної вени. За даними медичної літератури у людей виявлено вірогідні відмінності в складі клітин капілярної та венозної крові, але ці відмінності становили 3 - $6 \%$. та не виходили за межі референтних інтервалів (Mingacheva, 2011). Подібні данні наведені і в зарубіжній медичній літературі, де встановлена вірогідна різниця в кількості лейкоцитів, але ця різниця незначна і не впливає на клінічне значення отриманих результатів (Hollis, 2012; Ponampalam et al., 2012).

Науковці і практичні лікарі ветеринарної медицини проводять порівняння в основному вмісту біохімічних показників в венозній та капілярній крові, так в роботах проводять порівняння газового складу крові та показників кислотно лужної рівноваги. Метою подібних робіт $є$ встановлення використання капілярної крові в автоматичних аналізаторах при тяжких станах тварин коли неможливо швидко взяти венозну кров (Van Sluijs, 1983; Ferasin and Nguyenba, 2008).

Мета роботи. Порівняти результати гематологічних досліджень крові $з$ вушної вени, очного синуса та краніальної порожнистої вени взятої у одних і тих же поросят для виявлення відмінностей в кількості формених елементів .

\section{Матеріал і методи досліджень}

Кров відбирали вранці натщесерце, у 7 поросят, яким проводили пункцію вушної вени, орбітального синусу, краніальної порожнистої вени (КПВ) (Nikitin, 1956; Kibkalo et al., 2016). Від кожної тварини було відібрано по 3 проби крові. Для взяття крові були застосовані вакуумні системи забору крові фірми «FL medical vacumed». в крові визначали кількість еритроцитів і лейкоцитів, вміст гемоглобіну та проводили підрахунок різних форм лейкоцитів в мазку загальноприйнятими методиками (Kibkalo et al., 2016). Результати досліджень наведені на рисунку 1.

3 рисунку 1 видно, що значних достовірних відмінностей в кількісному складі крові (еритроцити, лейкоцити та гемоглобін) не виявлено. Найбільші відмінності виявлені у вмісті лейкоцитів, кількість яких мала тенденцію до збільшення у крові з очного синуса і була на $13 \%$ вищою ніж в інших судинах, але ця різниця не виходила за межі норми.

3 даних аналізу лейкоцитарного профілю найбільші відмінності виявлені в кількості еозинофілів вміст яких був вірогідно вищим $(\mathrm{p} \leq 0,001)$ в крові 3 вушної вени, слід зазначити, що цей показник був значно вищим від норми, що можливо пов'язано з патологічним процесом, але їх вміст в крові краніальної порожнистої вени та очного синуса був в межах норми. Тому, це питання потребує подальшого дослідження. Також виявлено вірогідно менший $(\mathrm{p} \leq 0,01)$ рівень лімфоцитів в крові $з$ вушної вени. В порожнистій вені взагалі не виявлено моноцитів та базофілів на відміну від очного синусу та вушної вени в останній їх виявлено найбільше. 


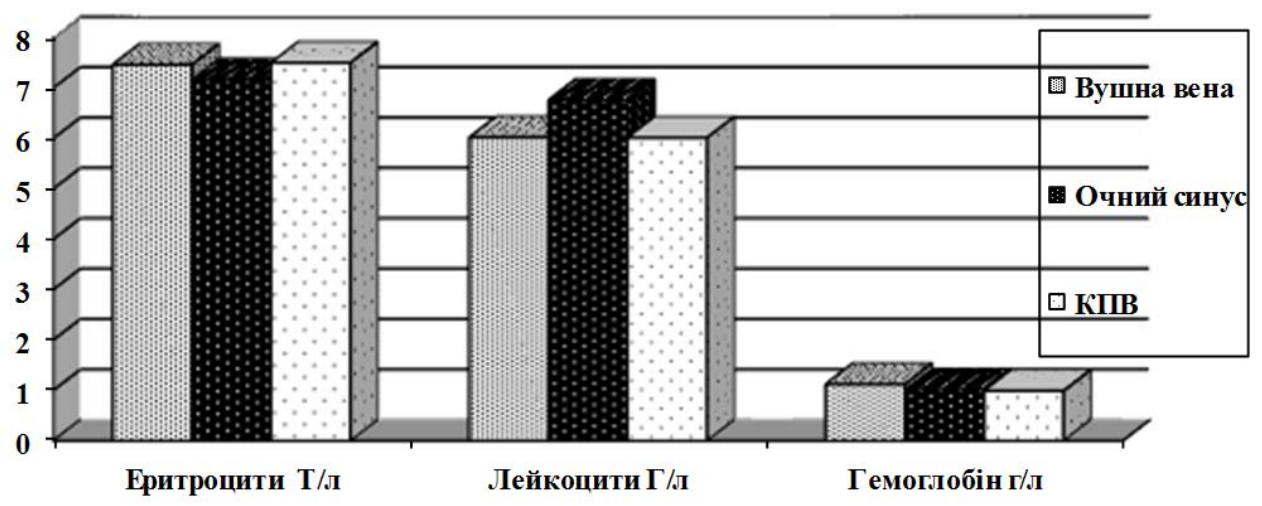

Рис. 1. Вміст еритроцитів, лейкоцитів та гемоглобіну в різних судинах у поросят

Лейкограмма крові свиней взятої з різних вен $(\mathrm{M} \pm \mathrm{m}, \mathbf{n}=10)$

Табличя 1

\begin{tabular}{|c|c|c|c|c|c|}
\hline & & КПВ & Очний синус & Вушна вена & Норма \\
\hline \multirow{4}{*}{ 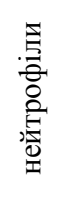 } & м \% & - & - & - & - \\
\hline & ю \% & - & $0,33 \pm 0,21$ & $0,25 \pm 0,25$ & $0-2$ \\
\hline & $\Pi \%$ & $10,40 \pm 1,98$ & $6,17 \pm 0,91$ & $7,25 \pm 1,77$ & $2-4$ \\
\hline & $\mathrm{c} \%$ & $28,80 \pm 3,65$ & $25,17 \pm 2,6$ & $26,5 \pm 1$ & $40-48$ \\
\hline \multicolumn{2}{|c|}{ еозинофіли, \% } & $2,20 \pm 0,58$ & $3,83 \pm 0,75$ & $15,13 \pm 1,53 * * *$ & $1-4$ \\
\hline \multicolumn{2}{|c|}{ моноцити, \% } & - & $0,67 \pm 0,21$ & $1,25 \pm 0,37$ & $2-6$ \\
\hline \multicolumn{2}{|c|}{ базофіли, \% } & - & $0,33 \pm 0,21$ & $1 \pm 0,38$ & $0-1$ \\
\hline \multicolumn{2}{|c|}{ лімфоцити,\% } & $63,50 \pm 4,16$ & $63,5 \pm 2,29$ & $48,63 \pm 2,21 * *$ & $40-50$ \\
\hline
\end{tabular}

$*_{-} \mathrm{p} \leq 0,05, *^{*}-\mathrm{p} \leq 0,01, *_{*} *_{-} \mathrm{p} \leq 0,001$ порівняно із КПВ

Виходячи із вищевикладеного можна зазначити, що в крові периферичних вен реєструється більша кількість гранулоцитів, які в подальшому стануть тканинними макрофагами. Нейтрофіли, моноцити, базофіли та еозинофіли володіють здатністю прикріплятися до стінок капілярів та дрібних судин чим забезпечують клітинний імунітет. В крові центральних судин більше лімфоцитів, що забезпечує гуморальний імунітет в кров'яному руслі.

\section{Висновки}

Кількість еритроцитів гемоглобіну та лейкоцитів в різних судинах достовірно не відрізняється, тобто місце та спосіб взяття крові не впливає на результат кількісного підрахунку клітин крові. В лейкоцитарному профілі крові поросят встановлені наступні відмінності: вірогідно більша кількість еозинофілів в крові з вушної вени; кров порожнистої вени та очного синусу містила вірогідно вищу кількість лімфоцитів; в крові з порожнистої вени не виявлено моноцитів та базофілів.

Для кількісного визначення формених елементів кров можна використовувати кров з різних судин, для підрахунку різних форм лейкоцитів кров потрібно відбирати з периферичних судин.

Перспективи подальших досліджень, провести порівняння результати гематологічних досліджень крові, зроблених на автоматичному гематологічному аналізаторі з вушної вени, очного синуса та краніальної порожнистої вени взятої у одних і тих же поросят.

\section{Бібліографічні посилання}

Kibkalo, D.V., Vikulina, G.V., Borovkova, V.M. ta in. (2016). Porivnjal'na ocinka riznyh metodiv vzjattja krovi u svynej. Problemy zooinzhenerii' ta veterynarnoi' medycyny: Zb. nauk. prac' HDZVA. 1620 (in Ukrainian).

Borovkova, V.M. (2015). Vplyv preparatu «Ljukon» na rezystentnist' porosjat $\mathrm{V}$ period vidluchennja. L'vivs'kyj nacional'nyj universytet veterynarnoi' medycyny ta biotehnologii' im. S.Z.Gzhyc'kogo. 8-11 (in Ukrainian).

Nikitin, W.I. (1956). Gematologitscheckij atlac cel'ckochosjajctwennych i laboratornych zhiwotnych. Mockwa: Gocisdat cel'chos. lit. (in Russian).

Levchenko, V.I. (2010). Metody laboratornoi' klinichnoi' diagnostyky hvorob tvaryn. Kyi'v: Agrarna osvita (in Ukrainian).

Mingacheva, A.A. (2011). Sovershenstvovanie preanaliticheskogo, postanaliticheskogo jetapov gematologicheskih issledovanij : avtoref. dis. na zdobuttja nauk. stupenja kand. med. nauk: spec. 14.03.10 «Klinicheskaja laboratornaja diagnostika». Mingacheva. Saratov (in Russian).

Hollis, V.S. (2012). Comparison of venous and capillary differential leukocyte counts using a standard hematology analyzer and a novel microfluidic impedance cytometer. PloS one. 7, 9, 43702.

Ponampalam, R., Fook Chong, S.M.C., Tan, S.C. (2012). Comparison of full blood count parameters using ca- 
pillary and venous samples in patients presenting to the emergency department. ISRN Emergency Medicine.

Ferasin, L., Nguyenba, T.P. (2008). Comparison of canine capillary and jugular venous blood lactate concentrations determined by use of an enzymatic- amperometric bedside system. American journal of veterinary research. 69, 2, 208-211.

Van Sluijs, F.J. (1983). Capillary and venous blood compared with arterial blood in the measurement of acidbase and blood gas status of dogs. American journal of veterinary research. 44, 3, 459-462.

Стаття надійшла до редакиії 27.09.2016 